\title{
Managing external imbalances in Montenegro - will faciliate integration to EU
}

\author{
Danijela Jacimović ${ }^{1, *}$, Slobodan Lakić ${ }^{1}$, Milos Rajković ${ }^{1}$, and Tamara Backović Vulić ${ }^{1}$ \\ ${ }^{1}$ University of Montenegro, Podgorica, Montenegro
}

\begin{abstract}
Montenegro as a new state has had similar approach to the development models as other European transition economies. High openness to foreign investments andeuroisation have influenced high liquidity, fiscal and financial expansion. With the current crisis, Montenegro is experiencing significant slowdown of economic activity, external imbalances, shortage of foreign capital, low credit activity, fiscal tightening and increase of public debt. This article aims to investigate the main effects to balance of payment imbalances in Montenegro. It compares economic indicators with the Eurozone countries, especially with the countries of the Eurozone periphery, trying to find similiraties and differences and possible policy recommendations, based on the experience in the Eurozone.
\end{abstract}

\section{Introduction}

Montenegro as a new and small country has faced a long standing development problem how to acellerate growth with a gap between domestic investments and domestic savings. However, high level of investments were needed for growth generation and future potential convergence to the EU market. Domestic savings were at a low level at the beginning of 2000 , with no prospect of dramatic change in the future. In these circumstances, fostering growth means orientation to foreign capital and foreign finances, to fill the gap. Following this strategy, Montengro has reduced most of the balance of paymet restrictions.

With the history of macroeconomic imbalances during 90s in Montenegro, one of the big challenges was how to manage macro indicators and future effects of high capital inflow at the same time. As it was practice in most Central and East European countries, the "rational was to join a currency union with a larger economic area, especially if the country has current account deficit" reported in (Rusek, 2002).

Montenegro adopted a foreign currency (Euro) as a legal tender by a unilateral decision in 2002. In economic sense, dollarization/euroisation is an extreme monetary regime where the country has the hardest of hard pegs. Countries dollarize in order to restore monetary stability, to promote a reliable and efficient payment system and to impose fiscal stability. Economic reasoning in Montenegro was to facilitate preserving of price stability and to contribute to fostering economic growth, as well as making better environment for foreign investments as a result of a stable inflation and lower interest rates.

\footnotetext{
*Corresponding author: danijelaj@ac.me
} 
As a small and fully euroisated economy, Montenegro experienced a great inflow of capital, credit boom, increase of domestic demand in the period 2000-2009. Despite the generous capital flows, foreign capital in Montenegro was more oriented towards providing quality international services to domestic markets "such as banking, telecommunication, retail sector and real estate and less in tourism and other export-oriented services. Therefore, investments in the service sector had a minor contribution to the export performance or competitiveness of Montenegro, but significantly contributed to import." (Mencinger,2007).

Bjelić, Jaćimović and Tasic (2013) say that "investments in manufacturing sector were significantly lower than the share of foreign investments in the sector of services". The manufacturing sector, "which has an influence on increasing of export and increasing of competitiveness", was a destination of a small number of foreign direct investments, unfortunately(Jaćimović, 2012; Mitra, 2011).

The level of import of goods in Montenegro exploded in 2008 and after that it was adjusted to the crisis circumstances. In the crisis time, Montenegrin balance of payment position, "especially current account position was seriously worsened, mostly due to weak export performance" (IMF, 2011). Strong increase of current account deficit, with low inflow of FDIs, forced the governments to borrow the missing capital from international financial markets. It "dramatically increased external and public debt and has put Montenegro in an unsustainable economic position in the long run" (Lakic and Jacimovic, 2014). In order to achieve sustainable growth, it is "very important to have sustainable current account position, which leads us to the conclusion about the importance of dynamic and growing export sector of goods" (RCC, 2013).

Under official euroisation since 2002, which was a political decision as Montenegro is not a member of the EU or Eurozone, Montenegro has experienced effects of global financial boom and severe effects of financial crisis afterwards. As a fully euroisation country outside the EU, in crisis time, it has suffered significantly, from not having all tools of monetary policy as other regional countries (depreciation of the currency to increse export revenues and decrease the current account balance) to fiscal tightening as a general rule, and nothaving all the financial assistance that the official Eurozone countries have had. The current crisis produces a lot of debate and opens questions about relationship, external imbalances, Euro, financial sector, domestic demand and fiscal measures, euroisation/dollarization.

Some recent studies find that the Eurozone debt crisis has influenced strong macroeconomic imbalances in member states, „but the roots of these imbalances can be found in the introduction of the common currency in 1999" (Sanchez and Varoudakis 2013;Belke, 2011; De Nicola at al. 2005). The main symptom of these imbalances was broadening of the current account deficit in the Eurozone perphery (Grece, Ireland, Italy, Portugal and Spain), matched by growing surpluses in the core (Austria, Belgium, denmark, Finland, France, Germany, the Netherlands and Slovenia).

There is growing academic literature on the causes of external imbalances in the Eurozone. Some findings (Wyplosy, 2013; Gross, 2010; Onaran, 2007; Galgoczi, 2007) show that "growing external imbalances in the periphery were mainly driven by domestic demand boom, led by greater financial integration (credit boom) and intra regional capital flows (as common currency eliminated exchange rate risk)". Most authors (Bernar A.B. at al, 2013; Goulier, 2013;Jaumotte and Sodsriwiboon, 2010) point out"that loss of competitiveness is another important reason for current account imbalances". For most periphery countries "loss of competitiveness was related to wage growth (especially in the public sector) and other business costs increase not following the productivity growth" (Papanikos, 2014; Trichet, 2011). A joint conclusion of several works (Eichengreen, 2010; Belke, 2011; 
Zemanek, Belke and Schable, 2009; Wyplosz, 2013)is that all this resulted in "an increase of external imbalance and debt crisis".

The main aim of this research is to follow the pattern of economic behaviour in the Eurozone countries (periphery) and compare it with the Montenegrin economic trends, analize factors affecting current account position, debating different economic policies, with the final goal - looking for a remedy.

The paper is organized as follows: Section two reviews effects of euroisation in Montenegro from the theoretical point of view and effects to the current account deficit. The third section discusses economic indicators associated with the current account imbalance. The fourth section presents anempirical model and results using specific VAR models.

\section{Euroisation in Montenegro}

The official euroisation in Montenegro replaced the German mark, so euro became an exclusive legal tender. Montenegro implemented the strategy of targeting the exchange rate based on the official (full) dollarization/euroisation. This targeting implies "importing" monetary policy of a big and stable trade partner. It starts from the assumption that in the developing countries loss of monetary policy independence may represent an advantage, i.e. producing better performances with somebody else's monetary policy. Targeting of the exchange rate turned out to be a successful strategy for fast reduction of inflation in undeveloped countries. However, experience leaves enough room for criticisms of official dollarization as a strategy (of the regime) without monetary policy or exchange rate policy, or impossibility to use the exchange rate as an instrument for facing external shocks.

Until the beginning of this century, the authors who studied the issues of monetary arrangements (Hanke i Schuler 1999; Berg i Borensztein 2000; Moreno-Villalaz 1999; Bogetic 2000; Mack, 2000 and others) gave an increasing support to the official dollarization. At the same time, the Panama experience was taken as a starting point, where the official dollarization was maintained more than anywhere else, but this monetary arrangement survived mainly owing to the IMF support. Experiences of the new dollarized regimes, including the one from Montenegro, could bring to opposite conclusions. In this context it is interesting to consult the following authors: Edwards i Magendzo 2001; Cespedes i Chang, 2001; Klein 2002; Chang and Velasco,2002; Mendoza,2002; Duncan,2003 and others. The research of official dollarization that followed include Jacome and Lonnberg (2010) and Swiston (2011).

According to Fisher (1996,2001),gross costs of dollarization are emphasized. Dollarization implies a loss of seigniorage as a source of real revenues - revenues from issuing activities of the central bank (issuing profit), such as: expenditures of the initial provision of cash in the currency of the dollarization country and loss of seigniorage after some years. The loss of the function of monetary authorities as lender of last resort, which potentially aggravates financial sensibility, may be compensated by a credit line of another institution (foreign commercial banks), monetary agreement with a foreign country or a multilateral institution. Also, there is no possibility of currency devaluation of financing a budget deficitby creating inflation, which would sometimes be desirable. During the nineties, there was a focus on encouraging trade integration with a dollarization country (linking business cycles). For example, Frankel i Rose (1997)estimate a significant increase of the trade/GDP ratio. However, Klein's model (Klein,2002) does not confirm the position that a currency union can encourage bilateral trade among its members or that this effect is big and statistically significant.

Among the users of official dollarization significant reduction of inflation is emphasized. Monetary stability is a crucial element of the recipe for growth and prosperity. A frequent opinion is that dollarization will bring to stability (reduction) of real interest 
rates. On the other hand, Chang and Velasco (2002) have clearly shown through their model that there is no possibility that dollarization itself will reduce interest rates. Edwards and Magendzo (2001) have analyzed a link between full dollarization with lower inflation and faster growth. They concluded that inflation would be much lower in dollarized economies, but that the rate of economic growth would be higher in non-dollarized economies. A lower growth rate is caused by the problem of adapting to external imbalances. Klein (2002) has shown that there is almost no evidence that dollarization stimulates trade of non-industrial countries with an anchor country. Eichengreen (2001) also believes that there is no confirmation that dollarization, just like any other exchange rate regime, is an important indicator of growth. This is contrary to the opinion of Dornbush (2001) that dollarization implies lower interest rates, higher investments and faster growth.

Elimination or significant reduction of currency risk of domestic currency would be an advantage of dollarization if the currency risk with other zones did not remain. Empirical research has shown that rational expectations imply an increase of the country risk. Although dollarization could increase real revenues or improve fiscal discipline and position, Edwards (2001) proposes that dollarization itself does not ensure fiscal solvency and caution. Stopping redistribution of wealth accummulated in the inflation period as well as the benefit of dollarization at the expense of those who live from fiscal revenues is not theoretically and practically justified. Despite the fact that a potential benefit is reduction of transaction costs, irrelevance of the argument is in a small ammount of costs. Extending the spectre of financial options aimed at increasing financial stability (reduction of market imperfection) cannot be considered in the context of standard models. The theory just points to the consequences of the expansion on allocations and wealth.

In a fully dollarized economy, the national monetary authority or a special domestic base money do not exist. The possibility of developing own monetary policy as a response to domestic economy is abandoned. The Central Bank is not constituted as a manager of the monetary system. Simplicity of the monetary system which prevents implementation of the monetary policy is based on three aspects: absence of a conventional central bank, independent exchange rate and autonomous monetary policy. According to the so-called monetary approach to the balance of payments, the quantity of base money is changed with the amount of the current balance of payment(e.g. Johnson 1972; Polak 2001; Ribnikar, 2004). Permanent surplus in the balance of payments (current and financial or capital part) is a condition for ensuring the necessary growth of the quantity of base money. Reduction of domestic prices and/or increase of interest rates bring to the necessary amount of the current balance of payment. The mechanism does not work when the prices have a rigid downward trend and/or when there is no adequate elasticity of international capital flow.

Due to an increased trust in the conditions of euroisation, after hyperinflation and other disturbances, the process of remonetization has accelerated. After the introduction of Euro, the participation of the amount of money in GDP has increased. The inflation rate, measured by retail price index, has significantly dropped, except in the initial period.

In case of Montenegro, intruduction of the Deutch mark (DM), firstly, and after that of euro was role of monetary strategy in the process of political separation of Montenegro and Kosovo from the third Yugoslavia.Weistbacher (2005) stated that the "political elites in these countries had discreet support" of USA and Germany, which led to "systematic isolation from Serbia“. Deutch Mark was introduced as the parallel official currency in 1999, and the year after that DM became the only legal tender. Since 2002, Montengro has used euro, as a non-member ofthe EU anda non-member of the Eurozone. Euroisation without an agreement with the European Central Bank was later acknowledged by the European Commission through a specific approach, and it happened due to "extraordinary circumstances" present in the country at the moment of introduction of euroisation. 
Montenegro mainly met the theoretical requirements for a successful implementation of euroization, such as the country size or opennes of its economy, but there remains an open question whether better results would have been achieved by a monetary-exchange rate arrangements based on a currency board. Some of the reasons for implementation of eurisation were low credibility of the creators of the monetary policies in this region and dramatic experience with the use of our own currencies.

Becker (2007) concluded that the replacement of national currency in Montenegro, firstly by the DM and ,later with euro, gradually brought down inflation, after many episodes of financial instability".However, other economic indicators have not recorded positive development. Montenegro, traditionaly, has had deficit in the current account deficit, based on low competitivnes level of the production sector.

Unfortunatelly, with introduction of a foreign currency, efects to external balance, especially current account balance werenot positive either. (Figure 1). Thus, Becker (2007) noted the following: „The euro has been highly problematic for the productive sectors in Montenegro and export performances, as appreciation of euro has hampered Montenegro export to Serbia, which represents about $30 \%$ of the total export".In the years of financial expansion, capital flows were balancing current accounts, making the overall situation more relaxing. But as the financial crisis appeared, the capital flows disappeared and current account position drastically worsened.

On the other hand, when euroization of the new EU member states is taken into account, euroisation was a part of the integration process. It was linked to the fulfilment of certain monetary criteria, but without real convergence. „The fast track strategy, in case of Eastern European countries, clearly demostrates the political character of the decision" (Mach, 2007).

Introduction of euro in Montenegro and to the new EU member states ,was purely political decision“ (Becker, 2007; Weistbacher 2005)In case of two countries (Monetengro and Kosovo), the reason for introduction of euro was separation, while in case of new member states it was integration.But the mentioned states have had more or less the same problems: "weak internal base, weak institutions and low level competitiveness and problems with current account balance"(Becker, 2007; March, 2007; Gligorov, 2003), which implies a lot of similarities between Montenegro and Eastern Europen counties.

This paper discusses the most important factors affecting significant current account problems, comparing the situation in Montenegro with the ountries of the EU periphery and core and looking for effective policy recommendations.

\section{Analisis of economic indicators affecting current account imbalances}

The biggest problem appearing in the Eurozone periphery states are disbalances in the current account balance of payments, which is also a big problem for all those countries that are linked in economic terms to the EU. This is especially characteristic of the countries that use Euro as a legal tender and are not a part of the monetary union, such as Montenegro. In this paper we will analyze all the similarities and differences in economic variables which influence the current account of the Eurozone states (core and periphery) and Montenegro.

Current account balance shows the level of international competiveness of a country. The countries with sufficit have large export and high savings but weaker domestic demand. On the other hand, countries with deficit have a large import, low saving rates and high expenditures expressed as a percentage of disposable revenues. Current account deficits accumulated throughout years require constant sources of funding, through net inflow of foreign direct investments, portfolio investments, then through credit transactions 
or at the expense of reducing foreign currency reserves of the country. External current account position for the Eurozone countries (core and periphery) and Montenegro for the period 2000-10, can be seenonFigure 1 .

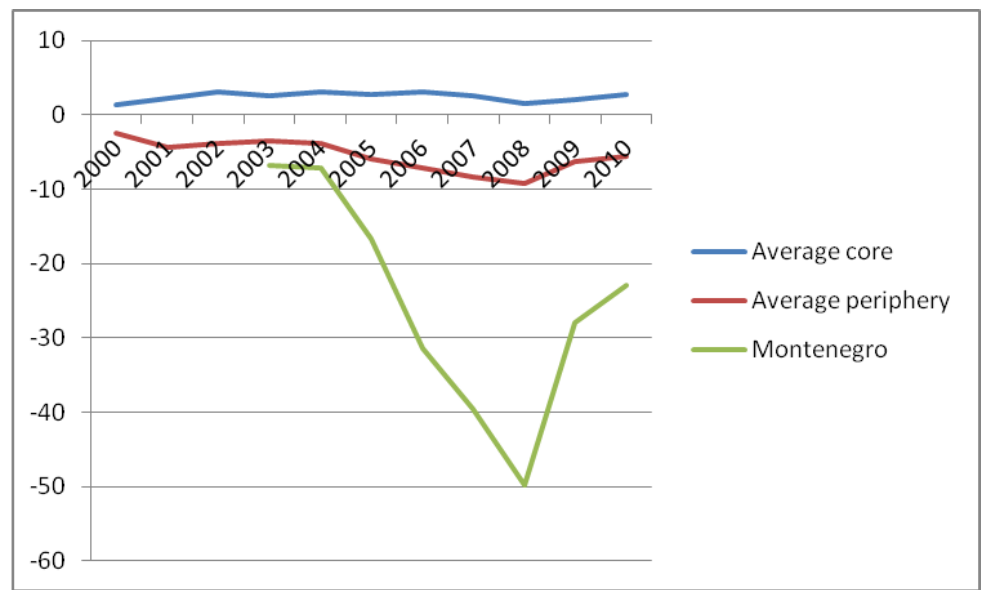

Fig. 1.External current account imbalances in the Eurozone core, periphery and Montenegro (in \% of GDP 2000-2010).

Most developed Eurozone countries mainly have lower continuous sufficit, while periphery countrieshave a prominent deficit. Montenegro has the highest deficit in Europe and at the peak of the 2008 crisis it reached $-49.8 \%$ of GDP.

The growing literature explains current account imbalances in the Eurozone and roots of the debt crisis. "Causes of Eurozone external imbalances are in the role of financial integration and domestic demand growth", asconfirmed by Blanchard and Giavazi (2002). And for filling current account deficit, most countries used external borrowing, whichwas mostly accepted as "good imbalances". It seemed to be"an opportunity for less advanced Eurozone countries to capitalize on financing integration through common currency by boosting investment and productivity growth"(Sanchez and Varoudakis, 2013;Cocozza, 2011; Kinoshita, 2011; Jaćimović, Bjelic and Tasic, 2012).

The reasons for a high deficit of the Montenegrin economy are high income of a part of population based on privatization and selling property, fosteringthe tendency to spending and a strong increase of demand, which is mainly manifested through import. Also, among other factors that influence high deficit are low competitiveness of the Montenegrin economy and a large import of energy sources. The basic sources of financing the current account deficit of Montenegro were foreign direct investments and loans, while during the crisis years it has been borrowing, because inflow of FDIs has reduced.

Montenegro uses euro as an official legal tender. Having this in mind, it can be concluded that the current account deficit of the balance of payments of Montenegro has lower risks than in the case of countries that have their own currencies, but the options for its elimination are reduced because policy of exchange rate cannot be used. It should be borne in mind that, when the sources of financing disappear and the time for repayment of debts come, the current account deficit may lead on a long-term basis to a reduction of money stock, which may have a recession effect on the economy.

Huge current account deficits were financed to a large extent by the banking sector.Credit dynamics of the core and perifery Eurozone countries and Montenegro is presented on Figure 2. 


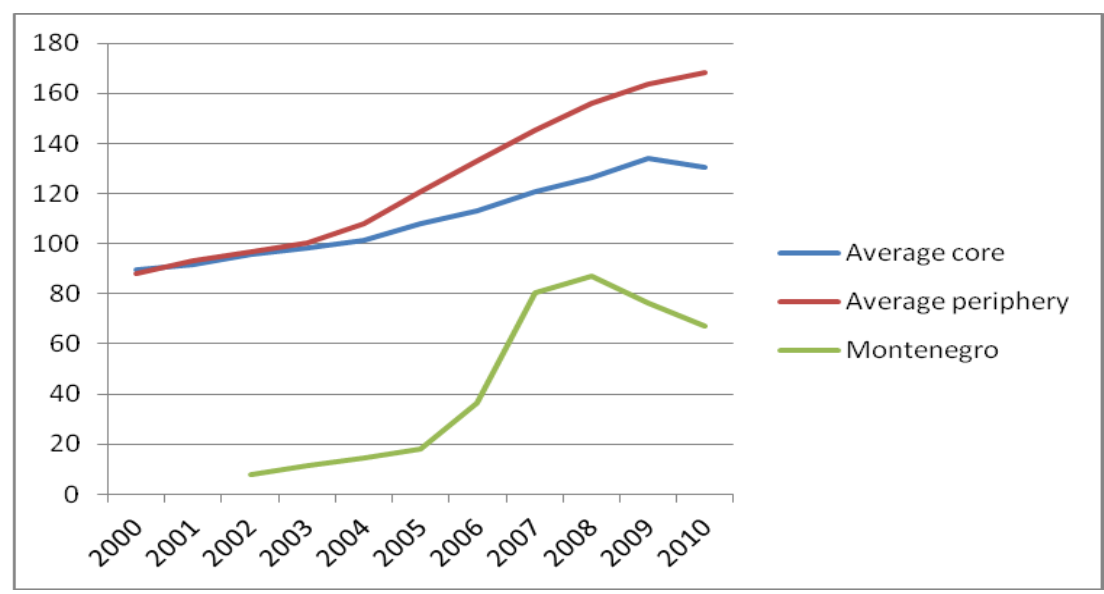

Fig. 2.Credit to private sector (in \% of GDP) in the Eurozone core, periphery and Montenegro (20002010).

Figure 2 shows credits given to the private sector, expressed as a GDP percentage for the period 2000-2010. Core and periphery EU countries have a constant growth which is more expressed in the core countries. Values for Montenegro are much lower, due to a very low starting point, but they had a fast growth in the years of expansion, even higher than in the Eurozone countries. Decline of the credit expansion has been evident after 2008 for all countries. The declining trend is by its intensity again stronger in Montenegro than in the Eurozone countries. It is a result of general recession trends due to the global economic crisis that has affected Montenegro too.

Credits to the private sector in the Eurozone were placed in much larger amounts than in Montenegro, but here lower starting point for Montenegro in early 2000s should be taken into account. At the beginning of the period, Montenegro had low growth rates of giving credits of 8.1 in 2002 and $11.3 \%$ of GDP during 2003. Due to transformation of the banking sector, placement increased in such a way that criteria for approving credits included a simplifed procedure. Financial bubble and inflated prices of real-estate cause ten-fold growth of credit activites to $87 \%$ of GDP in 2008. Disappearance of the investment euphoria and the global crisis caused a downward trend of credits given to the private sector, so in 2014 it was 53.5\%. Banks filled the domestic deposit potential to a large extent by borrowing from abroad or through credit lines of their headquarters abroad. Thus, the amount of banking credits in March 2009 was 50\% above banking deposits.

Credit stagnation was evident for the real sector in Montenegro after 2007, despite the measure of the Central Bank to increase the credit potential of banks by a set of measures and adapted policy of reserve requirements. The basic causes of a lack of new credits lie in the aggravated conditions for operation and risk growth that have affected the real sector. To enable growth of future credit activities, it will be necessary to provide additional state guarantees for bank credits to companies (actually at least a partial acceptance of the credit risk), a measure already largely used by developed economies such as German. Of course, growing deposit potentials allow credit growth.

Credit boom is usually linked with a decline of real interest rates, which represents a stimulative environment for this financial activity. Introduction of a single currency leads to reduction of interest rates, which has had an impact on the financial market of the periphery countries. Long-term state securities are usually taken as an indicator of real interest rates and due to a lack of indicators for Montenegro, we used interest rates on long-term deposits to monitor the level of interest rates. 
It is obvious that the credit risk, as a formal cause of the growth of interest rates, was bigger in the period of rise of economic activities. High interest rates are also one of the causes of negative performances in the financial system and economy, especially when in comes to business activities and unemployment. In the period of rise of interest rates, the Central Bank of Montenegro did not undertake the measures belonging to its competences to limit interest rates. Lack of instruments of monetary policy represents a limiting factor for determining the price of bank funds. In the absence of sovereignity over monetary policy, the Central Bank of Montenegro may have a limited function of a liquidity manager, based mainly on managing the reserves requirements, without the function of a lender of last resort. A serious lack of a monetary regime in Montenegro is the cost of the loss of a flexible monetary policy and exchange rate policy. Interest rates on long-term deposits are presented on Figure 3.

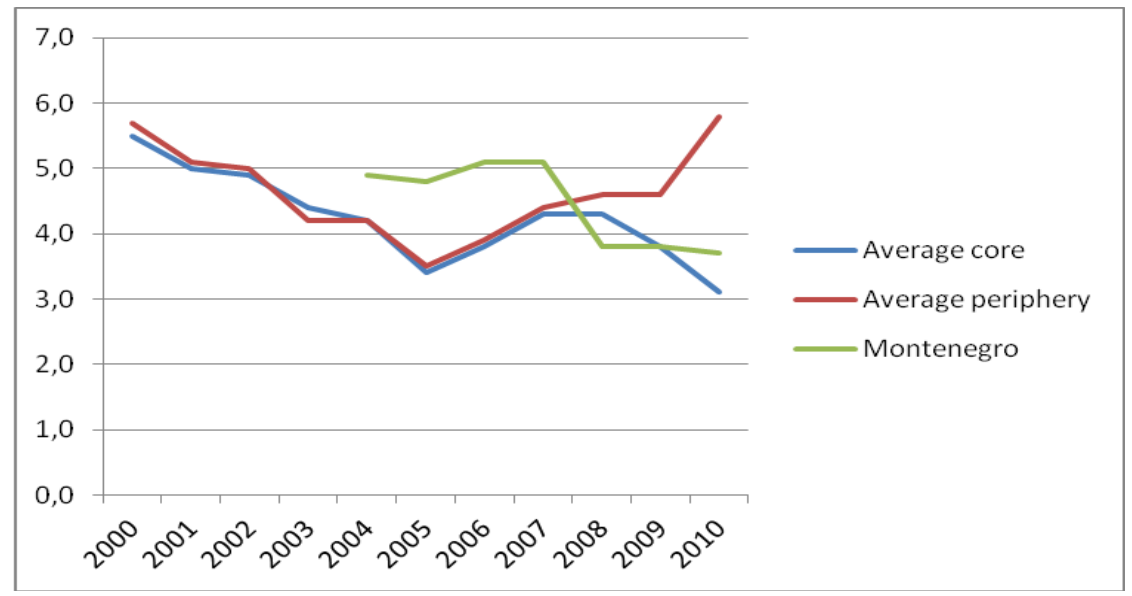

Fig. 3.Interest rates on long term deposits in the Eurozone core, periphery and Montenegro (20002010).

It is possible to see from the data on Figure 3 that the movement of interest rates for the core and periphery EU contries had a declining trend until the outburst of the crisis in 2007. With the outburts of the economic crisis these rates in the EU periphery states grew significantly, while in the core countries they dropped equally strongly. That was largely caused by withdrawal of capital from the periphery countries.

In order to regain trust in the banking system and attract deposits, Montenegro offered much higher interest rates than the EU states in early 2000s, having in mind a bad starting point and a higher risk. With the outbreak of the crisis, interest rates dropped and their level has been stabilized in the last several years, at the level between interests rates of core and periphery of the EU.

The practice of easier obtaining of credits with high liquidity of the financial system, followed by reduction of interest rates in the Eurozone (core and periphery) had a positive effect on investments, but it was destimulating for savingsin these countries. The scope of investments in the observed countries is provided in Figure 4. 


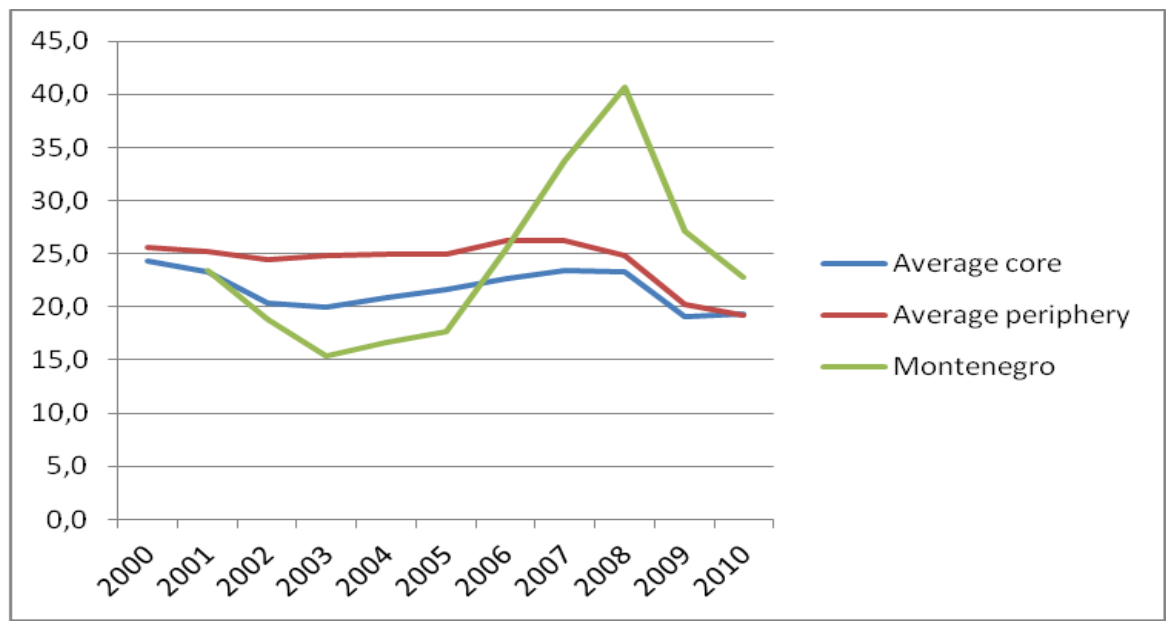

Fig. 4.Gross investment rate (in \% of GDP) in the Eurozone core, periphery and Montenegro (20002011).

As expected, the scope of investments was much bigger in the periphery countries than in the core countries in the observed period 2000-10, and the total amount of investments dropped with the outbreak of the financial crisis. The negative trend of gross investments was also evident in 2008 and 2009. In the EU members states, the scope of gross investments recovered in 2010, which was largely a consequence of the growth of their own capital and reinvesting of revenues. On the basis of the amounts providedon Figure 4, the trend of movement of gross investments is presented and it is very similar for both core and periphery EU states, with somewhat higher values for periphery countries. The total investments in the EU are on average a bit lower than one-fifth (below 20\%) of GDP.

With a large inflow of foreign direct investments during 2006, 2007 and 2008, Montenegro achieved very high indicators of gross investment rate in \% GDP, which then suddenly dropped in 2010, with a trend of approaching the values reached by the EU member's states. The gross investment rates in 2008 amounted to the excellent $40.7 \%$ of GDP and the period that followed saw their sudden decline, so the rate was halved and amounted to $22.8 \%$ of GDP in 2010.

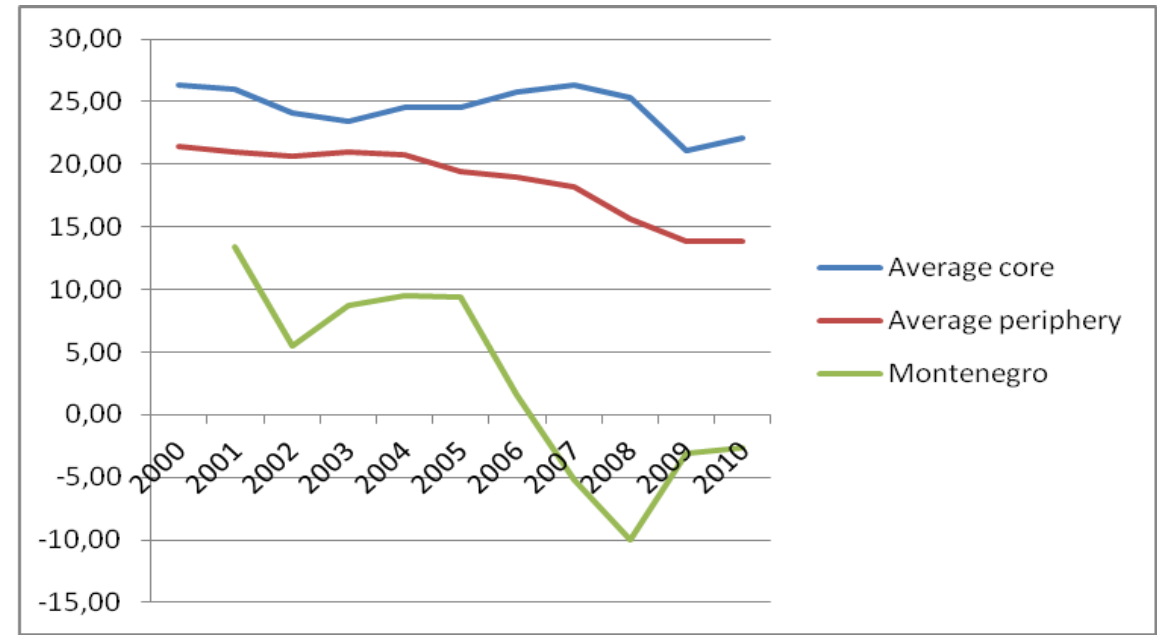

Fig. 5.Savings rate (in \% of GDP) in the Eurozone core, periphery and Montenegro (2000-2010). 
The significant investment activity influenced the saving rates in the observed countries. From the data presented on Figure 5 we can see that the scope of savings is highest in the core countries, where it was $27 \%$ to $22 \%$ of GDP in the period $2000-2010$. The effects of the financial crisis influenced a decline of the saving scope, when the periphery countries experienced a significant drop, from $22 \%$ to $13 \%$ of GDP in the same period. The turning point was 2009, when, after a decline of the scope of saving characteristic for the core and periphery countries, savings increased in the core countries and dropped in the periphery countries. The values for Montenegro oscillated. There was an evident growth between 2002 and 2006, followed by a declining trend, while values were much lower than the European average.

The phenomenon of negative saving rates was characteristic for Montenegro since 2007. This was possible due to higher availability of credits, but also spending that exceeded budget revenues. During the expansion in 2007 and 2008, the saving rate reached the values of $8 \%$ and $-14 \%$ of GDP. This influenced increased domestic demand, leading to huge consumption, which caused a significant current account deficit. This caused a short-term economic growth based on the growth of domestic demand, but it was not sustainable because it meant both higher consumption and indebtness. Negative rates persisted in Montenegro from 2007 to 2010.

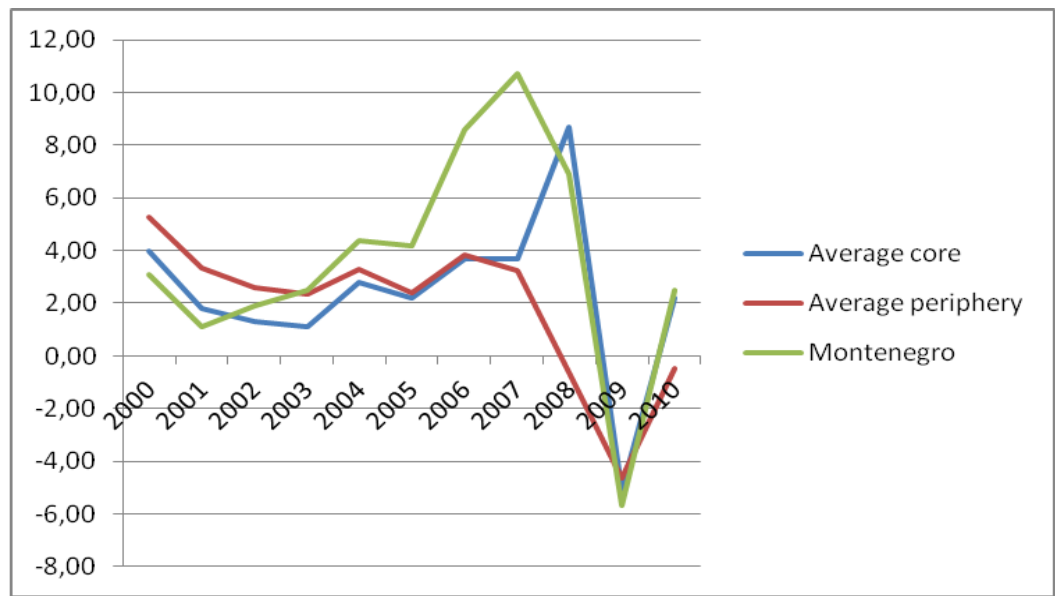

Fig. 6. Real GDP growth (in \% per year) in the Eurozone core, periphery and Montenegro (20002010).

A strong investment activity, reduction of savings along with a growth of domestic demand should lead to the GDP growth in the observed countries. Based on the data from Figure 6, it is possible to conclude that, when it comes to the EU periphery countries, the growth rate was $1-2 \%$ higher than the growth rates of the core countries, before the crisis broke out. Still, according to the findings of numerous authors (Negrelli and Signovetti, 2014; Sanchez and Varoudakis, 2013) "a powerful growth of the periphery countries is dominantly linked to the growth of domestic demand rather than due to the growth of labour force productivity, causing that the achieved growth lasted for a short time".

With the outbreak of the economic crisis in 2007, GDP continued to grow until 2009 in the core countries, while it had a significant decline as of 2007 in the periphery countries. After 2009, a precipitous decline of the value of GDP growth was a common characteristic of both core and periphery EU countries. Montenegro had positive and growing rates of economic growth and they were higher than in the core countries, and after 2003 even higher than the periphery countries. This can be explained by a low starting point. The achieved growth was especially obvious in 2006 and 2007, when it reached growth rates 
that were twice higher than in the observed EU member states. After "proclamation of independence in 2006, Montenegro enjoyed three years of a fast GDP growth of more that $9 \%$ on average" (CBCG, 2010). The reason can be found in the global financial expansion, as well as due to the effect of gaining independence. Since 2009 Montenegro has seen a decline of the economic growth, while the growth rate of Montenegro follows the growth rates in the EU zone.

The fiscal policy in achieving economic growth had a limited role in all the analyzed countries. Respecting the Maastricht criteria within the Eurozone caused the situation in which fiscal indicators do not differ between the center and periphery countries. Montenegro, which is not a Eurozone member, while it uses euro and negotiates with the member states and the European Commission, has accepted to respect the Maastricht criteria in the process of EU integration. Before the crisis broke out, all the countries had applied serious fiscal policies, increase of fiscal sufficit and low public debt. It was only the financial crisis that influenced the appearance of deficit and public debt, which was more prominent in the periphery EU countries and Montenegro. Trends of the budget deficit for the observed countries can be seen on Figure 7.

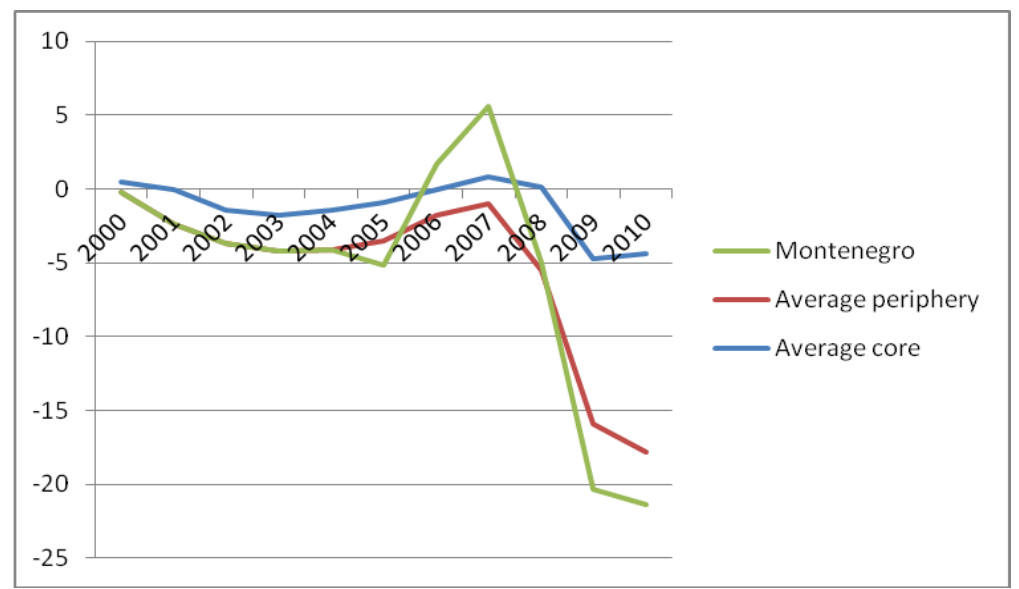

Fig. 7.Fiscal balance (in \% of GDP) in the Eurozone core, periphery and Montenegro (2000-2010).

On the other hand, "the link between growth and labour cost is becoming interesting", which has been pointed out by the European Commission in the European Parliament (2012). Still, it can be said that in the periphery Eurozone countries and Montenegro "the growth of labour cost exceeded the productivity growth, which led to appreciation of the exchange rate and decline of competitiveness in these countries" (Papanikos, 2014; World Bank, 2014;Sinn, 2011; CBCG,2010).

\section{Empiricalmodel of external imbalance in Montenegro}

Identification of the most influential factors on balance of the current account was done by using specific VAR models. In this paper several VAR models are estimated and every model has only two variables, because of the limited number of observation in the sample. In each VAR model one of those two variables is balance of the current account (CA - in percentage of GDP). The other one is: annual real growth rate of GDP (GR), savings (SAVINGS - in percent of GDP), credit to private sector (CREDIT - in percent to GDP), primary fiscal balance (PFB - in percent of GDP), per capita GDP of Montenegroin proportion to the per capita GDP of the average of the European Union (YGAP), total cost of labour to nominal GDP (COST) and gross investment rate (INVEST). 
Based on the Hannah-Quinn, Akaike information, and Bayesian information criteria, one lag is found to be enough to eliminate any autocorrelation in the residuals for VAR specifications which include variables GR, SAVINGS, CREDIT and PFB, but two lags are found in VAR models with YGAP, COST and INVEST.

The results presented below are based on impulse responses (IR) and variance decompositions (VD) methodology. Impulse response functions show the effects of shocks on the adjustment path of the variables. Forecast error variance decompositions measure the contribution of each type of shock to the forecast error variance. Both computations are useful in assessing how shocks to economic variables reverberate through a system.

Figureical representation of the impulse response function, based on specific VAR model, is given in Figure 8.

Response to Cholesky One S.D. Innovations

Response of GR to CA

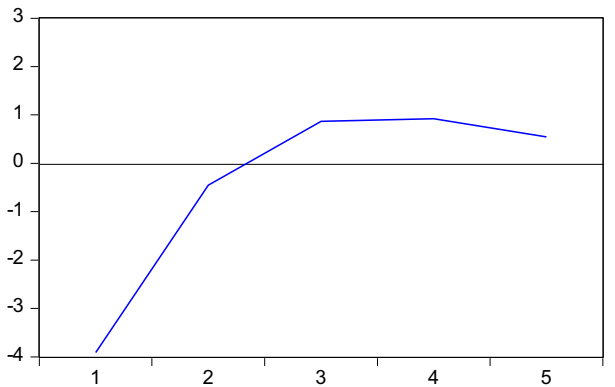

Response of CA to GR

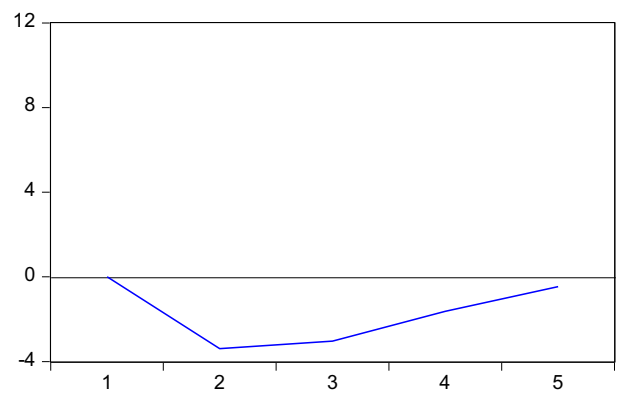

Fig. 8.Impulse response function for Current Account and Growth Rate of GDP.

Results of IR function in VAR model with CA and GR variables shows that the change in the value of balance of the capital account will have immidiate influence on the growth rate of GDP. The correlation of changes is negative in the first two years and after that the positive change in CA variable will apperently lead to a positive change in the growth rate of GDP. On the other hand, if the value of GDP growth rate rises, it will not change the value of balance of the current account. The change will appear after one year and will be negative till the end of the 5-year period.

\section{Response to Cholesky One S.D. Innovations}

Response of $\mathrm{D}(\mathrm{YGAP})$ to $\mathrm{CA}$

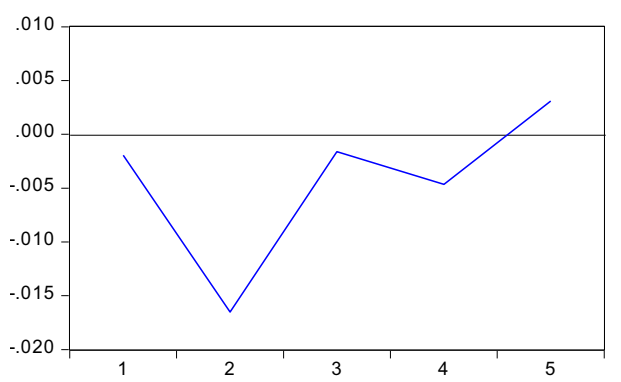

Response of CA to D(YGAP)

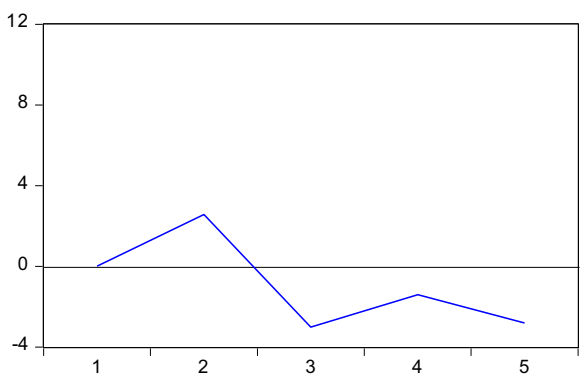

Fig. 9. Impulse response function for Current Account and the proportion of GDP in Montenegro and average GDP in EU.

Impulse response function for VAR model with CA variable and the first difference of YGAP variable, represented in Figure 9, shows that the rise of the value in current account will imidiately depreciate the proportion between GDP in Montenegro and average GDP in EU. This depriciation trend of YGAP will continue in the next two years and will slowly 
recover. If we have appreciation of the variable YGAP it will not change the value of the current account in the first six 18 months, this change of YGAO will lead to a positive change in the current account, but then the current account will depreciate until the end of this analyzed 5-year period.

Response to Cholesky One S.D. Innovations

Response of SAVINGS to CA

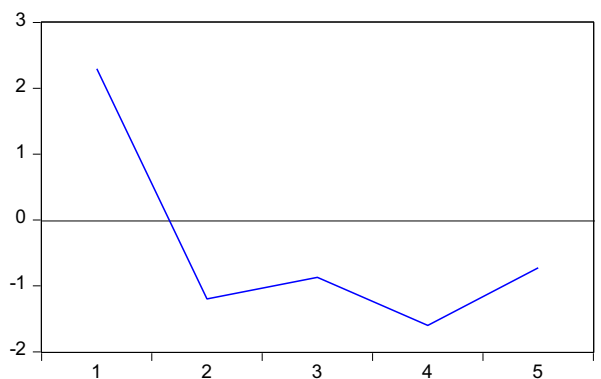

Response of CA to SAVINGS

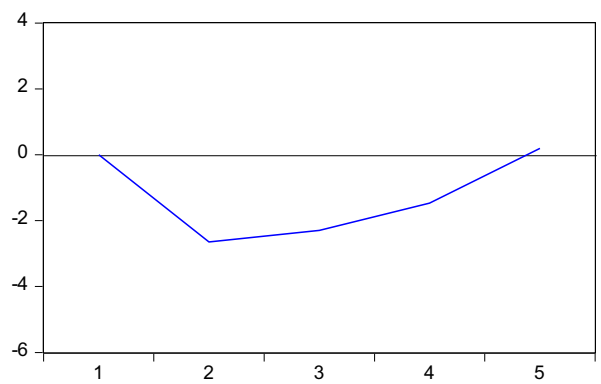

Fig. 10.Impulse response function for Current Account and the value of Savings.

Based on Figure 10 it can be concluded that if there is a positive change in the current account it will appreciate the savings in the first 18 months, but then the value of savings will fall. On the other hand, the rise of the savings value will not imply a change in the current account in the fisrt year, but after that the change of the current account will be negative. The effect of the saving change on the current account will disappear after five years.

\section{Response to Cholesky One S.D. Innovations}
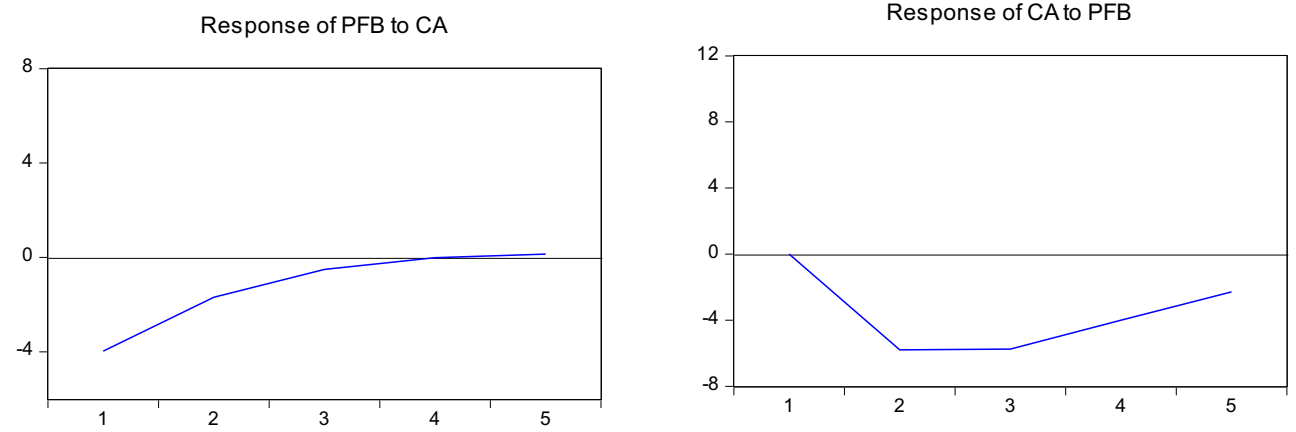

Fig. 11.Impulse response function for Current Account and the Primary Fiscal Balance.

If there is a positive change in the current account, this will lead to a negative change in the primary fiscal balance in Montenegro, based on the representation of Figure 11. This influence of the current account change on primary fiscal balance will vanish after 5 years. If we have a change on the primary fiscal balance side, this will cause a negative current account balance change after one year, but this effect will also disappear after 5 years. 
Response of D(CREDT) to CA

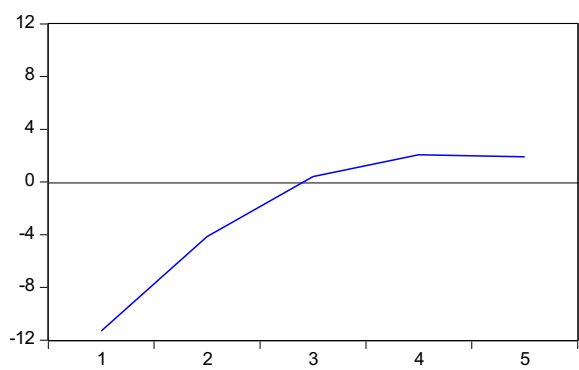

Response of CA to D(CREDT)

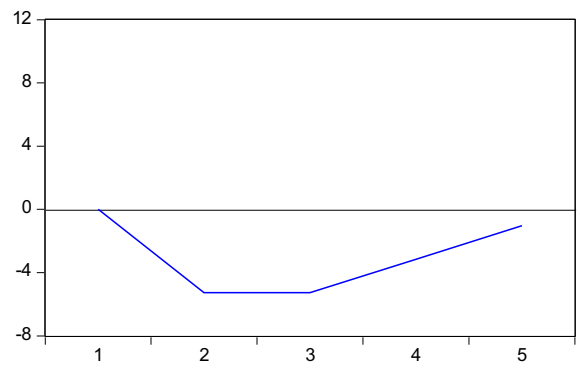

Fig. 12.Impulse response function for Current Account and the value of Credits to Private Sector.

Figure12 shows that the rise in the curent account balance will cause a negative change in the value of credits to private sector. This negative effect will turn into positive one after two and a half years. But the change in the value of credits to private sector will have a negative impact on the current account balance starting from the second until the fifth year of chance occurence.

Response to Cholesky One S.D. Innovations
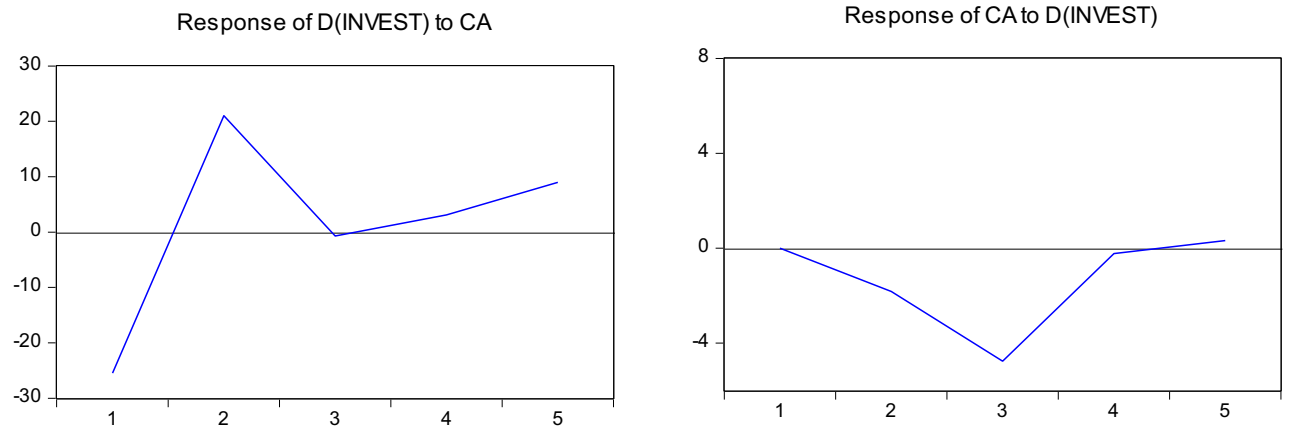

Fig. 13.Impulse response function for Current Account and the value of Investments.

In case where the positive change appeared on the investment side, balance of the current account will stay at the same level in the first year, based on Figure 13. But after one year, this rise of investment value will depreciate the value of current account and this effect will be present until for the next four years. But the change of the current account will depreciate the value of investment in the fisrt year, then appreciate investemnt value until the end of the 5-years period.

Response to Cholesky One S.D. Innovations
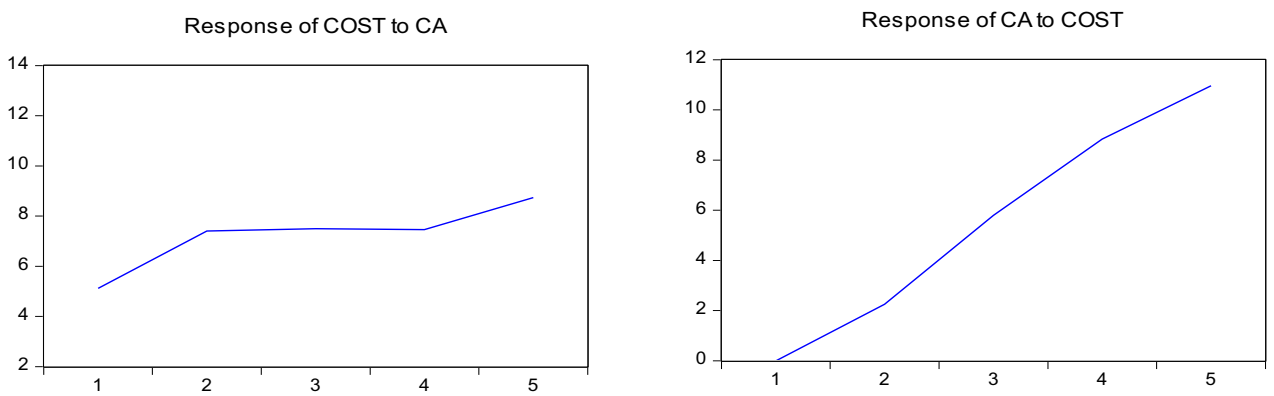

Fig. 14.Impulse response function for Current Account and the value of Labour Costs. 
Figure 14 represents the only variable whose change will immidiately influence a change of the current account balance, and that variable is a labour cost. There is a positive correlation between those two variables. Therefore, the positive change of labour cost will imply positive changes in the current account and vice versa.

The second part of the practical analysis in this paper is related to variance decomposition. The goal of variance decomposition is to investigate how much variations of all mentioned variables provide variability of unexpected changes in the balance of the current account in Montenegro.

According to the results of variance decomposition given in the Table 1, in the second year after GDP growth rate changes, it will influence balance of current account change for $6.27 \%$, but that value of CA change is aproximately $10 \%$ in the fourth year.

Table 1. Variance decomposition for Current Account and Growth Rate of GDP.

\begin{tabular}{|c|c|c|c|}
\hline \multicolumn{4}{|c|}{ Variance Decomposition of CA: } \\
\hline Period & S.E. & CA & GR \\
\hline 2 & 13.55937 & 93.72685 & 6.273151 \\
\hline 4 & 15.18913 & 89.84481 & 10.15519 \\
\hline
\end{tabular}

In the next step, we chekhed how much variation of ratio of GDP in Montenegro to GDP in EU will cause the unexpected change of the current account. The results are shown in Table 2. The results confirm that YGAP change will cause CA to change by $3.18 \%$ in the second year and $7 \%$ in fourth year.

Table 2. Variance decomposition for Current Account and the proportion of GDP in Montenegro and average GDP in EU.

\begin{tabular}{|c|c|c|c|}
\hline \multicolumn{4}{|c|}{ Variance Decomposition of CA: } \\
\hline Period & S.E. & CA & D(YGAP) \\
\hline 2 & 14.35932 & 96.81402 & 3.185981 \\
\hline 4 & 15.92746 & 93.02810 & 6.971898 \\
\hline
\end{tabular}

If there is a change in the savings level, it can cause the change of the current account by $17.74 \%$ in the second and $16.79 \%$ in the fourth year. Representation of the variance decomposition is given in Table3.

Table 3. Variance decomposition for Current Account and the value of Savings.

\begin{tabular}{|c|c|c|c|}
\hline \multicolumn{4}{|c|}{ Variance Decomposition of CA: } \\
\hline Period & S.E. & CA & SAVINGS \\
\hline 2 & 6.287633 & 82.25327 & 17.74673 \\
\hline 4 & 9.277291 & 83.20334 & 16.79666 \\
\hline
\end{tabular}

In Table 4 variance decomposition of the current account balance shows that changing the primary fiscal balance can influence the change of the current account by $25 \%$ in the second and $43 \%$ in the fourth year. This is also the highest value of change in the balance of the current account correlated to the change of the external factor, variable.

Table 4. Variance decomposition for Current Account and the Primary Fiscal Balance.

\begin{tabular}{|c|c|c|c|}
\hline \multicolumn{4}{|c|}{ Variance Decomposition of CA: } \\
\hline Period & S.E. & CA & PFB \\
\hline 2 & 11.58693 & 74.99769 & 25.00231 \\
\hline 4 & 13.83107 & 56.73349 & 43.26651 \\
\hline
\end{tabular}


Credit value change can influence the current account change by up to $17.16 \%$ in the second and $28.81 \%$ in the fourth year. The results of variance decomposition are presented in the Table 5.

Table 5. Variance decomposition for Current Account and the value of Credits to Private Sector.

\begin{tabular}{|c|c|c|c|}
\hline \multicolumn{4}{|c|}{ Variance Decomposition of CA: } \\
\hline Period & S.E. & CA & D(CREDIT) \\
\hline 2 & 12.71591 & 82.83577 & 17.16423 \\
\hline 4 & 15.07136 & 71.18791 & 28.81209 \\
\hline
\end{tabular}

Variance decomposition results of the current account shown in the Table 6 imply that if there is a change in the investment it can cause an unexpected change in the current account by $4.22 \%$ in the second year and $16 \%$ in the fourth year.

Table 6. Variance decomposition for Current Account and the value of Investments.

\begin{tabular}{|c|c|c|c|}
\hline \multicolumn{4}{|c|}{ Variance Decomposition of CA: } \\
\hline Period & S.E. & CA & D(INVEST) \\
\hline 2 & 8.887866 & 95.77566 & 4.224343 \\
\hline 4 & 12.75205 & 83.96770 & 16.03230 \\
\hline
\end{tabular}

At the end of this analysis, based on the results given in Table 7., we can conclude that the change of labour cost can cause an unexpected change of the current account by $2.7 \%$ in the second year and surprisingly high change in the fourth year of $32.29 \%$.

\section{Conclusion}

Montenegro was in a group of the fastest developing European economies in transition in the observed period. However, this "growth was not influenced by a growth of productivity" (IMF, 2011), but by a high balance of payments deficit of over $25 \%$ of GDP annually, which was covered by a net inflow of foreign direct and portfolio investments, and later by borrowing. The model of growth of the Montenegrin economy in that period was based on a significant foreign capital inflow, which encouraged credit expansion, overheating of demand, which led to an unreal increase of prices of property (real estate and especially shares) and economic growth above potential, which was not sustainable on a long-term.

Unsustainability of the economic growth contributed to an "inappropriate structure of foreign investments, which was in the amount of $90 \%$ directed to non-tradable goods, (retail, services, real estate)" (Lakic and Jacimovic, 2014; Bijelić, Jaćimović and Tasic, 2013;Đurović and Jaćimović, 2012; Jaćimović, 2012;Becker and Weissenbacher, 2011, 2012; Cocozza at al., 2011; Mencinger, 2007). The capital flows were mainly directed towards non-tradable sectors, where an "increase of productivity is limited, which did not lead to an increase of export" (RCC, 2013). On the other hand, "Euro has been higly problematic for the productive sectors in Montengro and export performances"in (Becker, 2007). (Euro's apreciation has hampered Montenegro export to Serbia, which represents about $30 \%$ of the total export).

A key finding of our empirical analysis is that current account fluctuations in Montenegro have made other macroeconomic indicators change and it was hard to identify the factors which can have a big influence on the current account change. Impulse response function of specific VAR model suggests that only cost of labor can be the one and only factor with great impact on the current account movement (level of competitiveness).

On the other hand, variance decomposition methodology identifies three most important indicators which contribute to the variance of the current account in the 4 -year period. The 
first and the most influential factor is a primary fiscal balance which can cause the current account change by approximately $43 \%$ at the end of the fourth year. It seemsthat fiscal policy could have a great effectivness in restoring external balance equilibrium, so stronger fiscal discipline is recommended.Another very important factoris the labor cost with the impact on current account variation by $32.3 \%$, where the labor costs contagion can play an important role in thelevel of competitiveness and external imbalances. The credits to private sector and the effect on the current account fluctuation is $28.8 \%$ in the 4 -year period.Regulating banking market and credits to the private sector should be one of the priorities, primarily for the purpose of reducing concentration of the placed funds into nontradable sectors, along with stronger limits regarding housing lending.

The effects of the crisis represent a fruitful ground for debate on the necessary structural reforms in Montenegro aimed at finding an appropriate combination of economic policies which would lead to an increase of competitiveness, export and stabilization of the current account of the balance of payments. Achieving sustainable growth on a mid-term basis is imposed as a priority, and the results provided through an empirical model can serve as a framework for future policies.

\section{References}

1. J. Becker, Dollarization (Metropolis-Verlag, Marburg, 2007)

2. J.Becker, R. Weissenbacher, Growth models (Politics and Economics, Belgrade, 2011)

3. A.Belke, C. Dreger, Deutsches Institute fur Wirtschaftsforschung, 1106(2011)

4. A.Berg, B. Eduardo, Finance and Development1, 21 (2000)

5. A.B.Bernard,R.Massari,J.D.Reyes, D.Taglioni, World Bank Policy Research Working Paper 6711, 52 (2011)

6. P.Bijelić, D.Jaćimović, I.Tašić, Čigura print 196,71-98 (2013)

7. O.Blanchard, F.Giavazzi, Brookings Papers on Economic Activity2, 147-186 (2002)

8. Z.Bogetic, Cato Journal2, 179-213 (2000)

9. Centralna banka Crne Gore, Radna studija 19, 65 (2010)

10. L.F. Cespedes, R. Chain, NBER Conference on Crisis Prevention1, 43 (2001)

11. R.Chang, A. Velaso, National Bureau of Economic Research 8838, 32 (2002)

12. E.A. Cocozza,A.Colabella, F. Spadafora, International Monetary Fund 11, 300 (2011)

13. G.De Nicoló,P.Gianni, A. Ize, Journal of Banking and Finance 29(7), 1697-1727 (2005)

14. R.Dornbush, Massacushetts Institute of Technology, 8326 (2001)

15. R.Duncan, Central Bank of Chile Working Paper, 249 (2003)

16. R.Duncan, Central Bank of Chile Working Paper, 243 (2003)

17. G.Đurović, D. Jaćimović, Global Science Tehnology Forum 2, 120-127 (2012)

18. S.Edwards, National Bureau of Economic Research 8324, 76 (2001)

19. B.Eichengreen, K.R.Andrew, National Bureau of Economic Research 7432, 65 (2001)

20. European Parliament, Macroeconomic Imbalances in the Euro Area (Internal Policies, Brussels, 2012)

21. S.Fischer, Stability and the Exchange Rate System in a Monetarist Model of the Balance of Payments(The Political Economy of Monetary Reform, Allahand, 1996)

22. S. Fischer, Journal of Economic Perspectives 15(2), 3-24 (2001) 
23. J. A. Fontaine, Cato Journal 1, 32 (2000)

24. J.A. Frankel, A. K. Rose, Economic Journal 1, 1009-1025(1998)

25. B. Galgoczi, Dollarization(Metropolis-Verlag, Marburg, 2007)

26. G.Gaulier, G.Santoni,D.Taglioni, S.Zignago, World Bank Policy Research Working Paper 6733, 47 (2013)

27. V.Gligorov, Current Analysis and country profiles 19, 21 (2003)

28. D.Gros, CEPS Policy Brief 266, 87 (2012) 